\title{
OS MECANISMOS NECESSÁRIOS PARA A MANUTENÇÃO DA DEMOCRACIA
}

\author{
Vivian de Almeida Gregori Torres ${ }^{1}$ \\ Waleska Cariola Viana ${ }^{2}$
}

\section{RESUMO:}

O estudo toma como marco teórico o pensamento filosófico de Robert Dahl e Hanna Arendt para abordar o tema democracia, destacando-se na análise histórica-filosófica a importância da participação popular para a existência e manutenção da democracia enquanto a tradução da vontade popular na condução do Estado e da vida em sociedade.

Palavras-chave: Democracia, Democracia Direta, Democracia Representativa, Democracia Participativa, Ferramentas da Democracia Participativa.

\section{THE APPARATUS NECESSARY FOR THE MAINTENANCE OF DEMOCRACY}

\section{ABSTRACT:}

The study takes as a theoretical framework the philosophical thinking of Robert Dahl and Hanna Arendt to address the theme of democracy, highlighting in the historical-philosophical analysis the importance of popular participation for the existence and maintenance of democracy while the translation of popular will in the conduct of State and life in society.

Key words: Democracy, Direct Democracy, Representative Democracy, Participatory Democracy, Tools of Participatory Democracy.

\section{INTRODUÇÃO}

Tomamos como marco teórico o pensamento filosófico de Robert Dahl e Hanna Arendt para abordar o tema democracia, destacando-se na análise histórica-filosófica a importância da participação popular para a existência e manutenção do Estado de Direito.

Assim, o trabalho está dividido em quatro capítulos, destinando-se o primeiro ao enfoque histórico-filosófico e os seguintes a abordagem teórica das espécies de democracia -

\footnotetext{
${ }^{1}$ Doutora em Direito do Estado pela Faculdade de Direito da Universidade de São Paulo. Mestre em Direito Político e Econômico pela Universidade Presbiteriana Mackenzie. Especialista em Direito Empresarial pela Universidade Presbiteriana Mackenzie. Graduada pela Faculdade de Direito de São Bernardo do Campo. Professora na Universidade Nove de Julho. Membro do Comitê Científico da Revista Eletrônica de Direito Eleitoral e Sistema Político - ReDESP da Escola Judiciária Eleitoral Paulista - EJEP. Presidente da Comissão de Pesquisa e Pós-Graduação em Direito da OAB/SP. Vice-Presidente da Comissão de Propostas de Parcerias e Convênios Públicos da OAB/SP. Membro Efetivo da Comissão de Ensino Jurídico da OAB/SP. Relatora da $2^{\mathrm{a}}$ Câmara do Tribunal de Ética e Disciplina da OAB/SP. Conselheira da OAB/SP. Advogada e Professora do Ensino Superior na Faculdade de Direito da Universidade Nove de Julho (UNINOVE).

${ }^{2}$ Mestre em Direitos Humanos Fundamentais pelo Centro Universitário Instituto de Ensino para Osasco (UNIFIEO); Especialista em Direito Civil-Empresarial e Processo Civil pela Faculdade de Direito Professor Damásio de Jesus; Graduada em Direito pelo Centro Universitário das Faculdades Metropolitanas Unidas (FMU). Professora do Ensino Superior na Faculdade de Direito da Universidade Nove de Julho (UNINOVE).
} 
direta, indireta e semidireta - e das ferramentas da democracia representativa e participativa, tecendo críticas para o aprimoramento e ampliação da aplicação desses institutos de forma a fortalecer a participação popular, elemento essencial do Estado de Direito.

Concluímos que para evitar cairmos nas armadilhas do oferecimento de facilidades e vantagens óbvias e imediatas dos regimes autoritários, tais como a estabilidade, a segurança e a produtividade, a cultura política e as convicções democráticas são tão essenciais para o desenvolvimento da consciência aos cidadãos da necessidade vital de participação, em condições iguais, nas discussões de assuntos de relevância para o interesse comum, aliado ao fato de que tal participação popular não fique apenas em debates, mas que efetivamente as intenções expressadas por palavras se manifestem e se identifiquem com as ações para que a forma pura de governo democrático não se transforme em sua versão impura, a demagogia, que por sua vez acarreta o descrédito e o enfraquecimento do espírito cívico dos cidadãos.

Por isso, tão importante a consciência da importância da educação para criação de uma cultura democrática e de cidadania - no sentido empregado por Hannah Arendt que é 'o direito a ter direitos' e assim 'poder defender os seus direitos' - para o aprimoramento e a ampliação da aplicação de ferramentas que possibilitem o exercício da participação popular, pois não é interessante para a democracia nem o escoamento do interesse popular, nem o seu transbordamento por falta de caminhos para que efetivamente seja aproveitado.

\section{Democracia: aspectos históricos}

Filósofos e historiadores afirmam que o surgimento da democracia remonta à Grécia, há 2.500 anos, no período axial, no ano 509 a.C (século V a.C), no governo de Clístenes ${ }^{3}$,

3 Estadista, filósofo, político e legislador grego nascido em Atenas, cujas reformas políticas contribuíram para despertar o sentimento de cidadania em contraposição à solidariedade dos membros do clã e assim considerado o fundador da democracia ateniense. Da família dos Alcmeônidas, conhecida por sua oposição à tirania, era neto de Clístenes de Sicião, por parte materna. De uma época em que a aristocracia ansiava por reverter as reformas políticas impostas por Sólon. Depois da luta pelo poder que se seguiu à queda do tirano Hípias (510 a. C.), a assembleia popular de Atenas entregou-lhe o governo da cidade. Introduziu reformas democráticas baseadas na isonomia, princípio pelo qual todos os cidadãos tinham os mesmos direitos, independentemente da situação econômica e do clã ao qual estivessem filiados. Alterou a organização social, que 
anterior ao governo de Péricles, este equivocadamente nomeado por muitos como o "pai da Democracia".

Clístenes, de Atenas, iguala os cidadãos em zonas (circunscrições) chamadas demos. Esses homens, reconhecidos como cidadãos, nessas zonas, eram considerados iguais.

Assim, originariamente, democracia (demo) significa uma zona territorial, um local para se debater as coisas da polis ${ }^{4}$.

No entanto, estavam excluídos da condição de cidadãos: as mulheres, os escravos, os servos, os estrangeiros e os comerciantes, estes porque não tinham o ócio ("nec otium" origem da palavra negócio), no sentido de não ter "otium cum dignitate", ou seja, o cidadão para estar envolvido com as preocupações da polis deve estar tranquilo, não ter preocupações com o labor para poder se dedicar a ação para as coisas da polis ${ }^{5}$.

Como se pode perceber, na Grécia, a democracia era exercida por uma minoria de homens denominados cidadãos. Ainda, assim, distingue-se essa forma de governo da aristocracia (governo por uma classe privilegiada, seja por conhecimentos, seja em razão do nascimento) e da oligarquia (forma impura do governo aristocrático), por se tratar de uma

de quatro tribos baseadas em laços de sangue, dividiu a população ateniense em dez, misturando homens de diferentes origens e condições. Cada uma delas era integrada por habitantes das três áreas, denominadas trítias, em que a cidade ficou dividida. As trítias, por sua vez, se subdividiam em demos, numa estrutura que pretendia diluir a influência local das famílias poderosas, abolir o caráter tribal da sociedade ateniense e imprimir-lhe características de cidade. Elevou para 500 os membros do Conselho de Sólon, com cinqüenta representantes de cada tribo, escolhidos pelos demos em número proporcional à população de cada um deles. Introduziu a execução dos condenados à morte por envenenamento com ingestão de cicuta e a pena do ostracismo, cassação de direitos políticos daqueles que ameaçassem a democracia ateniense. Morreu em Atenas e, a partir de suas reformas, essa cidade converteu-se na maior potência econômica da Grécia (490-470 a. C.). Suas ideias inspiraram a definição de democracia seguida por reformadores de todos os tempos, ou seja, o princípio da igualdade é direito de todos e a participação ativa de todos os cidadãos na vida pública. Este brilhante idealista acreditou nos direitos iguais de todos os cidadãos, e como uma consequência teve muitos inimigos na oligarquia, mas aparentemente morreu de morte natural, em sua cidade natal. Disponível em:

http://www.dec.ufcg.edu.br/biografias/Clistene.html. Acesso em: 20 jul. 2013.

4 "designação que abarca tanto o território, quanto a população que o habita. E sem suprimir estes institutos, a evolução alcança finalmente a pólis, a cidade, que lhes dá a necessária conformação política e unidade" (AZEVEDO, 1999, p. 6).

5 "De fato, a sociedade grega, escravista, destinava ao homem de pensamento o tempo livre, o 'ócio com dignidade', utilizado para a elevação e emancipação, para a contemplação do belo, para a discussão em torno do útil e do justo. Na cultura grega, cabiam aos cidadãos a organização e comando da pólis. Ao cidadão era proibido o trabalho braçal, por necessitar ter tempo livre para se dedicar à reflexão e ao exercício da cidadania e do bom governo". (DANTAS, 2006, p. 123) 
forma de governo que garante a todos os cidadãos a isonomía, a isotinía e a isagoría e faz da liberdade e da sua observância a base sobre a qual repousa toda a sociedade política ${ }^{6}$.

Essa forma de governo de todos os cidadãos, esses entendidos como os que dispunham do ócio para se dedicar as coisas da polis (e não de todos indiscriminadamente) tem registro de existência também em Roma, embora os romanos preferissem chamar seu sistema de República: res (coisa) e publicus (pública) ${ }^{7}$.

Inicialmente, em Roma, o direito de participar do governo da República restringia-se aos patrícios, ou seja, aos aristocratas ${ }^{8}$.

A República Romana durou consideravelmente mais tempo que qualquer democracia, inclusive a Ateniense, porém em razão da corrupção, da inquietude civil, da guerra e do enfraquecimento do espírito cívico dos cidadãos, pereceu e transformou-se em outro regime, comandado por imperadores. ${ }^{9}$.

Com o desaparecimento da república romana, a forma democrática de governo desvaneceu e por cerca de mil anos foi substituída por monarquias, aristocracias, oligarquias e governos despóticos, todos com base em alguma forma centralizadora do poder em poucas pessoas ou grupos ${ }^{10}$. Somente ao final da Idade Média, a democracia ressurge na Itália.

O que se pode notar é que as condições favoráveis para o ressurgimento da forma democrática de governo se relacionam principalmente com o interesse dos indivíduos em lutar pelo seu reconhecimento como legítimos participantes das coisas da polis.

A história da democracia, assim como a do reconhecimento dos direitos humanos, é um relato de avanços e retrocessos e, por isso, segundo o entendimento de Fábio Konder Comparato, não há como falar em evolução histórica, mas sim em uma afirmação histórica. (COMPARATO, 2013, p. 09)

6 "Com a isonomia proclamava-se a igualdade de todos perante a lei, sem distinção de grau, classe ou riqueza. Com a isotimia, a organização democrática da Grécia abolia títulos e funções hereditárias e viabilizava a todos os cidadãos o acesso livre ao exercício das funções públicas e no conceito de isagoria reúnem-se os predicados de igualdade jurídica de falar e de participar da direção da coisa pública, em associação ao debate público dos negócios de governo" (DANTAS, 2006, p. 102).

7 DAHL, Robert. Sobre a Democracia. Brasília: UNB, 2001, p. 23.

$8 \quad$ DAHL, 2001.

$9 \quad$ DAHL, 2001, p. 24.

10 DAHL, 2001, p. 25. 
Tem-se, portanto, que a ideia de democracia se traduz num conceito histórico que se desenvolveu e se enriqueceu a cada etapa do evoluir social, mas sempre mantida a ideia central de tratar-se de um regime político em que o poder repousa na vontade do povo ${ }^{11}$.

Por óbvio, o conceito de povo também evoluiu, já que, na Grécia antiga, as mulheres, os negociantes, os estrangeiros e seus descendentes e os escravos estavam excluídos da participação nas coisas da polis e até há muito pouco, na maioria dos países tidos por democráticos, quase que a metade da população adulta, representada pelas mulheres, estava excluída da participação do sufrágio. ${ }^{12}$ A Nova Zelândia, em 1893, tornou-se o primeiro país a garantir o sufrágio feminino e, no Brasil, as mulheres passaram a ter o direito ao voto, mas com restrições, somente em $1932^{13}$.

Para se evitar a repetição de erros - por ação ou omissão -, é importante a análise e a compreensão dos acontecimentos passados que alertam quanto aos fatores que põem em risco a democracia.

Robert Dahl, em sua análise histórica sobre o surgimento, declínio e ressurgimento da democracia, aponta como fator de risco o desinteresse dos indivíduos em participar das coisas da polis, desinteresse decorrentes de várias origens como a corrupção, a oligarquia (forma impura de governo por um grupo), o declínio econômico, o descrédito nos representantes eleitos e nas instituições públicas, tudo a propiciar a eclosão de guerras, a conquistas e tomadas forçadas do poder por governantes autoritários, sejam príncipes, monarcas ou soldados. (DAHL, 2001, p. 24)

Hannah Arendt aponta como fatores que põem em risco a democracia o desinteresse quanto ao exercício do poder, a passividade (no sentido de aceitação) quanto aos ataques e infrações aos direitos, o individualismo e a alienação do mundo. (ARENDT, 1989, p. 11)

A corrupção que leva ao descrédito dos representantes eleitos e no desinteresse pela participação nas coisas públicas, aliada ao comodismo, ao individualismo e a atribuição de maior valor à segurança do que à liberdade são fatores que favorecem o ambiente para a instauração de regimes autoritários de governo. Sobretudo, o desestímulo do povo à
11 COMPARATO, 2013, p. 9.
12 DAHL, 2001, p. 13.
13 ALVES, 2014. 
participação dos assuntos de interesse público é uma forma de desvalorizar o seu poder o que resulta na sua perda.

Para Zygmunt Bauman, o desafio do mundo contemporâneo é a conciliação entre o individualismo e os interesses sociais (BAUMAN, 2001, p. 74). Na visão do autor, o desafio para o mundo contemporâneo e, também, uma tarefa das mais difíceis, é conciliar o individualismo com os interesses coletivos, pois as instituições e valores do passado, elos que entrelaçavam os projetos individuais aos coletivos, são referências estranhas à fase líquida ${ }^{14}$ da modernidade, em que, cada um por si tenta capacitar-se para as incertezas do futuro ${ }^{15}$.

Essa é a realidade da sociedade contemporânea, envolta em um ciclo vicioso do prazer em consumir, transformando o homem em um animal laborans, preocupado apenas com a satisfação dos seus instintos e necessidades vitais, um ser alheio ao mundo externo ${ }^{16}$. Nesse mesmo sentido, aponta Hannah Arendt que o individualismo e o consumismo são

14 Zygmunt Bauman desenvolveu o conceito de "Modernidade Líquida", na qual as ideias de emancipação, individualidade, tempo/espaço, trabalho e comunidade estão propensas a mudar com rapidez e de forma imprevisível. Em sua análise da Modernidade identificou os fenômenos do individualismo e do consumismo na sociedade. A modernidade líquida está obcecada por valores e isso acontece por se viver em um mundo cheio de oportunidades e este fato representa esse mundo cheio de possibilidades que a possibilidade de consumir não se restringe somente às coisas, mas também às ideias e as sensações. É um mundo de descartes, que envolve o indivíduo num ciclo de vida que resume-se ao trabalho e consumo. "Tudo corre agora por conta do indivíduo. Cabe ao indivíduo descobrir o que é capaz de fazer, ele se educa como consumidor orientado pelo desejo e conceitos como necessidade dão lugar ao de adequação. O consumo nessa modernidade fluida torna-se um ritual de exorcismo" (BAUMAN, 2001, pp. 74 e 94-96).

15

BAUMAN, 2001, p.12.

16 Na obra "A condição humana", Hannah Arendt faz a distinção entre labor, trabalho e ação - atividades fundamentais que integram a Vida Activa - bem como esfera pública, esfera privada e esfera social - local onde estas atividades são desenvolvidas. Segundo consta no posfácio a 10. ed. brasileira da obra, redigido por Celso Lafer: "labor é a atividade assinalada pela necessidade e concomitante futilidade do processo biológico, do qual deriva, uma vez que algo que se consome no próprio metabolismo, individual ou coletivo. Porque é a atividade que os homens compartilham com os animais, Hannah Arendt qualifica-a como a do animal laborans. $\mathrm{O}$ trabalho, ao contrário do labor, não está necessariamente contido no repetitivo ciclo vital da espécie. É através do trabalho que o homo sacer cria coisas extraídas da natureza, convertendo o mundo num espaço de objetos partilhados pelo homem. O habitat humano é, por isso mesmo, nitidamente diferente de qualquer ambiente natural. É um habitat cercado de objetos que se interpõem entre a natureza e o ser humano, unindo e separando os homens entre si. A ação, diz Hannah Arendt, 'é a única atividade que se exerce diretamente entre os homens sem a mediação das coisas ou da matéria, correspondem a condição humana da pluralidade, ao fato de que homens, e não o Homem, vivem na Terra e habitam o mundo". Como Bikhu Parech, citado por Celso Lafer, "no labor o homem revela as suas necessidades corporais, no trabalho a sua capacidade e criatividade artesanal; na ação a ele mesmo. A ação é fonte significativa da vida humana” (ARENDT, 2007, p. 345). 
fatores de alienação do mundo externo e, por isso, são os atuais inimigos de uma democracia. (ARENDT, 2007, p. 13).

Aliás, nota-se que as muitas críticas endereçadas à democracia representativa derivam da falta de participação dos cidadãos, que se alheiam ao processo, e se limitam, no máximo, a remoer queixumes, conforme entendimento expressado por Paulo Ferreira da Cunha (CUNHA, 2013, p. 51).

Na visão de Hannah Arendt, o conhecimento desse desequilíbrio é útil na medida em que auxilia a regular e equilibrar a balança, ou seja, a consciência da fluidez e da condição de animal laborans em que o consumo exacerbado coloca o homem, enredando-o num ciclo sem fim, que em uma visão otimista o levará a interessar-se pelas coisas comuns e a praticar ações que se perpetuem no mundo exterior, (ARENDT, 1989, p. 13).

Eis, então, a importância de compreender os fatos passados e refletir sobre a importância das atitudes de cada indivíduo nessa sociedade pós-moderna regida pelo consumo a fim de se evitar a repetição de erros e retrocessos na história da democracia como também na história dos direitos humanos.

A perda do poder, decorrente da falta de interesse pelo 'mundo externo' ou pelas 'coisas públicas', levam à sensação de inutilidade e descarte. Há que agir, no sentido de participar (praticar a ação) para não perder o poder; a utilidade.

Atualmente, os fatores de isolamento são a preocupação individualista exacerbada com o labor e o consumo, fatores que levam a alienação do mundo, como exposto no pensamento de Hannah Arendt. Esse é o atual risco para a democracia e que favorece sorrateiramente as condições para o surgimento de regimes autoritários, tal como nos alerta a autora.

Para afastar esses riscos à democracia e ao Estado de Direito, o melhor caminho é o incentivo à cultura política e às convicções democráticas, ou seja, de que a democracia é desejável e que depende da criação de mecanismos que garantam e incentivem a participação popular.

A cultura política e as convicções democráticas são tão essenciais e importantes para se evitar cair nas armadilhas do oferecimento de facilidades e vantagens óbvias e imediatas dos regimes autoritários - a estabilidade, a segurança e a produtividade, como também igualmente necessárias para o desenvolvimento da consciência da necessidade vital (tanto do regime, quanto dos próprios indivíduos) de participação em condições iguais para as 
discussões de assuntos de relevância para o interesse comum, aliado ao fato de que não fiquem apenas em debates, mas que efetivamente as intenções expressadas por palavras se manifestem e se identifiquem com as ações para que a forma pura de governo democrático não se transforme em sua versão impura, a demagogia, que por sua vez acarreta o descrédito e o enfraquecimento do espírito cívico dos cidadãos.

Sobre o tema, Paulo Ferreira da Cunha realiza a seguinte síntese que merece referência:

a democracia só é plena quando impregnar todas as instituições e tiver sólido suporte na consciência, no coração e nos hábitos das pessoas, a começar pelas que, de qualquer forma, exerçam o poder, ainda que a um nível mais baixo. A cultura democrática de um povo é a seiva que alimenta a normalidade da vida democrática das instituições pequenas e grandes. (CUNHA, 2013, p. 54)

Em países sem essas condições é muitíssimo improvável que a democracia se desenvolva e se mantenha.

Por isso, tão importante a consciência da importância da educação para criação de uma cultura democrática e de cidadania - no sentido empregado por Hannah Arendt que é 'o direito a ter direitos' e assim 'poder defender os seus direitos' - para a criação e a ampliação de mecanismos que possibilitem o exercício dessa participação popular, pois não é interessante para a democracia nem o escoamento do interesse popular, nem o seu transbordamento por falta de caminhos para que efetivamente seja aproveitado.

Em suma, o que se vislumbra é que o Estado de Direito é espécie de Estado que possui como elementos limitadores do poder os princípios da constitucionalidade e da legalidade, a separação dos poderes e os direitos fundamentais da pessoa humana, que são como o esqueleto de um Estado de Direito, sendo o princípio democrático a força que movimenta e dá sustentação a todo esse esqueleto, legitimando o poder constituído e o seu exercício.

A partir dessas ideias e levando em conta a evolução histórica do Estado de Direito, podemos classificá-lo em Estado Liberal de Direito, Estado Social de Direito, Estado Constitucional de Direito ou Estado Democrático de Direito que nada mais são do que expressões para definir com ênfase sócio-político-jurídica cada uma das fases da evolução do Estado de Direito. 
Sob o enfoque do elemento democrático, o que se pode dizer é que no Estado de Direito 'todo o poder emana do povo ${ }^{17}$ e tal participação popular é o combustível necessário que sustenta e movimenta o Estado de Direito, daí a importância da criação de mecanismos que propiciem o aumento da participação e da representatividade popular como forma de fortalecimento dessa forma de Estado.

\section{Das Espécies de Democracia}

A democracia é tema cuja definição tem sido perseguida por séculos, ${ }^{18}$ podendo-se identificar entre os estudiosos elementos que tanto coincidem como diferem, possibilitando uma vasta gama de tipos. ${ }^{19}$ Sob o prisma da convergência classificatória, tem-se a democracia direta (clássica ateniense), a indireta (representativa) e a semidireta (participativa), sendo que para a implementação de cada uma dessas é necessária a aplicação de ferramentas próprias a cada tipo.

A democracia direta ${ }^{20}$ é o autogoverno, no qual o próprio povo toma as decisões e coloca em prática as políticas públicas. Esse modelo foi experimentado na Grécia antiga e temos por parâmetro de tal experiência a democracia ateniense. Tomando-se por base esse exemplo pode-se dizer que as ferramentas, se é que se pode chamar de ferramentas, da democracia direta, eram a origem por nascimento, que dava o direito ao indivíduo de ser cidadão ateniense e, portanto, participar das assembleias e o sorteio que era utilizado para preenchimento dos cargos públicos.

17 'É conhecida a formulação de Lincoln quanto à 'essência' da democracia: 'governo do povo, pelo povo e para o povo’. Ainda hoje se considera esta formulação como a síntese lapidar dos momentos fundamentais do princípio democrático. Designamos a fórmula de Lincoln como um modo de justificação positiva da democracia". (CANOTILHO, 2003, p. 287).

18 "A democracia configura, na realidade, uma categoria histórico-social ajustando-se, nas suas variadas nuanças, à condição de cada povo, às peculiaridades de cada uma das sociedades, donde a extrema dificuldade de uma conceituação precisa." (CAGGIANO, 1987, p. 14).

19 "Pois bem, já restou assente a aridez do esforço conceitual do standard democrático, tarefa tão incômoda quanto, por exemplo, a de definir o vento (...) Não há como negar tais dificuldades, denunciadas, desde logo, pela larga variedade de propostas definitórias, cada qual privilegiando um dos elementos empregados na sua conformação final. Daí, também, a vasta gama tipológica, oferecendo categorias de tons e nuanças diferenciadas em razão da amálgama que lhe serviu de pauta.” (CAGGIANO, 1995, p. 53/54).

20 "A democracia direta, ou seja, aquela em que as decisões fundamentais são tomadas pelos cidadãos em assembleia (...)." (FERREIRA FILHO, 2010, p. 109). 
A democracia indireta é a representativa ${ }^{21}$, na qual o povo elege o candidato que irá tomar as decisões por ele. ${ }^{22}$ Monica Herman Salem Caggiano define a representação política como "um arranjo político constitucional em cujos quadros os governantes são eleitos pelos integrantes do corpo social e considerados seus representantes.”(CAGGIANO, 1987, p. 19).

Luis Sanchez Agesta expõe que a representação é uma forma de participação do povo no poder, um fenômeno de substituição e legitimação política, que através do voto direciona e organiza a ação da opinião pública e através dos partidos políticos organiza a política. (SANCHEZ AGESTA, 1979, p. 300).

A pedra fundamental da democracia indireta é a representação, sendo que o representante será definido com o auxílio dos partidos políticos e pelo voto. A questão reside no fato de que o voto sem consciência e impensado, feito de forma irresponsável, conduz à desorganização política, que é agravada pelos partidos no caso brasileiro, em razão de estarem enfraquecidos, homogeneizados, sem direcionamento e descomprometidos com um programa de governo. Os dois fatos somados resultam em um cenário no qual o cidadão acaba elegendo um representante que nada representa.

A democracia semidireta, participativa, é o modelo no qual o povo tem a possibilidade de intervir diretamente na tomada das decisões políticas, "é direta na medida em que o povo participa de modo imediato de certas decisões" (FERREIRA FILHO, 2010, p. 123).

Pode-se dizer que a democracia participativa é o desdobramento do princípio da soberania popular, aplicação de institutos de participação direta do povo nas funções do governo. Esse é o exercício do poder diretamente pelo povo, uma nova dimensão de democracia: a dos cidadãos.

\section{Ferramentas da Democracia Representativa}

\footnotetext{
21 “A democracia indireta é aquela onde o povo se governa por meio de 'representante' ou 'representantes' que, escolhidos por ele, tomam em seu nome e presumidamente no seu interesse as decisões de governo.” FERREIRA FILHO, 2010, p. 111).

22 "O verdadeiro poder do eleitorado é o poder de eleger quem o governará. Portanto, as eleições não decidem as questões mas quem irá decidi-las.”, tradução nossa. (SARTORI, 2007, p. 90).
} 
$\mathrm{Na}$ esteira da democracia representativa, tem-se como ferramentas viabilizadoras o voto, enquanto exercício do sufrágio, ${ }^{23}$ e os partidos políticos. ${ }^{24}$ Paulo Bonavides define o sufrágio como "poder que se reconhece a certo número de pessoas (o corpo de cidadãos) de participar direta ou indiretamente na soberania, isto é, na gerência da vida pública.” (BONAVIDES, 2012, p. 245). Já Márlon Reis, ao definir sufrágio, vai além do direito de votar, ser votado e participar da vida pública. Estende-o à forma de legitimação do exercício do poder. ${ }^{25}$

Para Monica Herman Salem Caggiano:

o direito de sufrágio, hoje, é erigido a um dos mais eminentes direitos em relação ao homem político, integrante de uma comunidade social, exatamente por lhe propiciar a participação no polo epicêntrico das decisões políticas, quer ativa, quer passivamente. A operação eleitoral, que gira em torno desse direito, consubstancia-se, em verdade, na mecânica a viabilizar a concretização da representação política. (CAGGIANO, 2004, p. 73)

J.J. Gomes Canotilho traz como princípios materiais do sufrágio: o princípio da universalidade, o princípio da imediaticidade, o princípio da liberdade, o princípio do voto secreto, o princípio da igualdade, o princípio da periodicidade e o princípio da unicidade. (CANOTILHO, 2003, p. 302/306)

O voto é a legítima expressão da vontade do povo, meio pelo qual escolhe quem melhor representa seus interesses; é uma forma de participação na decisão política ${ }^{26}$ e condução da coisa pública. ${ }^{27}$

23 "O sufrágio é um instrumento fundamental de realização do princípio democrático. Através dele, legitima-se democraticamente a conversão da vontade política em posição de poder e domínio, estabelece-se a organização legitimamente de distribuição dos poderes, procede-se á criação do ‘pessoal político' e marca-se o ritmo da vida pública de um país." (CANOTILHO, 2003, p. 301).

$24 \quad$ "O ponto culminante do processo governamental na democracia moderna é a eleição. Para muitos ela resume a democracia moderna. Essa identificação entre democracia e eleição é historicamente coisa nova. Os antigos não consideravam a eleição instrumento democrático e sim aristocrático. Para os helenos o método democrático por excelência era o sorteio.” (FERREIRA FILHO, 1979, p. 161/162).

25 "É um direito público subjetivo de natureza política, que tem o cidadão de eleger, ser eleito e de participar da organização e da atividade do poder estatal, por conseguinte o meio exclusivo de concretização do poder. Sua função é consubstanciar o consentimento do povo, que legitima o exercício do poder.” (REIS, 2012, p. 90).

26 "O voto em sua simplicidade, exprime com segurança uma escolha política concreta e não mera opinião abstrata.” (LEMBO, 1991, p. 53). 
Monica Herman Salem Caggiano, ao mencionar a fórmula concretizadora da representação política, qual seja, a eleição dos representantes que tomarão as decisões políticas fundamentais pelos representados, comenta que

Sob este traçado, a eleição passa a configurar um verdadeiro sistema: um arranjo político-constitucional, envolvendo o processo de escolha e designação dos representantes/governantes pelos integrantes do grupo social - os representados/governados. Estes, nesse contexto, pronunciam-se politicamente por intermédio de consulta eleitoral, selecionando seus representantes. (CAGGIANO, 2013, p. 25)

$\mathrm{Na}$ democracia representativa, o voto é tido como o meio do povo influir e participar das decisões políticas, de uma forma indireta que seja, mas in tese teria sua participação garantida.

No caso brasileiro, com a deterioração da qualidade do político, que busca a eleição apenas para conjugar seus interesses ao do Estado e, com isso, se locupletar o máximo possível, não se pode afirmar com exatidão que o atual modelo de democracia representativa garante a participação do povo na decisão política. Os brasileiros estão indo para as ruas, fazendo protestos, tentando tomar para si, de volta, a decisão política. É uma releitura moderna da democracia ateniense feita na praça pública.

Segundo José Afonso da Silva, os atributos do voto são eficácia, sinceridade e autenticidade, sob as características básicas da personalidade e da liberdade, pelo que, o eleitor deverá estar presente no momento do voto para expressar sua preferência por um candidato sem qualquer interferência ou coação. (SILVA, 2005, p. 218/219)

Sobre esses aspectos, deve-se ponderar sobre os novos meios de coação e interferência no voto brasileiro, que retiram sua sinceridade e autenticidade, tais como a pressão psicológica promovida pelos partidos no sentido de imposição do medo, no eleitorado, de perder os benefícios alcançados no caso do partido que está no poder perder tal circunstância e a utilização de "marqueteiros" que produzem um candidato esteriotipado, de

\footnotetext{
27 "Demais disso, atuam como instrumento para, promover o controle governamental e, por outro lado, expressar a confiança nos candidatos eleitos. E mais que isso, na condição de lócus de participação política, as eleições autorizam a mobilização das massas, todo um processo de conscientização política e de canalização dos conflitos mediante procedimentos pacíficos. Contribuem, ainda, para a formação da vontade comum ...”

(CAGGIANO, 2004, p. 74).
} 
forma a esconder a essência verdadeira do proponente ao cargo, elegendo-se alguém que não corresponderá ao pretendido. $^{28}$

As distorções e ingerências operadas pelo marketing afetam diretamente a liberdade do sufrágio e empossam representantes desarmonizados com o eleitor ${ }^{29}$, nas palavras de Claudio Lembo: "esta deformação da comunicação eletrônica desnatura a democracia" (LEMBO, 2006, p. 10).

É certo que o voto, na democracia brasileira, padece de algumas patologias. Contudo, ainda assim é a melhor ferramenta da democracia representativa, podendo ser aprimorada com o tempo.

Outra ferramenta da democracia representativa são os partidos políticos. Esses são os condutores das necessidades sociais para o governo, servem de freio às paixões e tumultos que os problemas sociais poderiam ocasionar, bem como organizam o período eleitoral. Segundo Maurice Duverger, o surgimento dos partidos políticos está relacionado à evolução democrática e ao sufrágio universal, trata-se da organização progressiva da massa votante. (DUVERGER, 1957).

O partido político foi elencado como ferramenta da democracia indireta, tomando-se por base a democracia pelos partidos e, especialmente, o exemplo brasileiro, no qual o candidato obrigatoriamente tem que estar filiado a um partido político para poder concorrer a um pleito eleitoral. A representação, portanto, só se efetiva com a eleição do escolhido e, para tanto, ele deverá ser filiado a algum partido. Ou seja, sem partido não há representação. ${ }^{30}$

Claudio Lembo expõe que ao partido político é conferido o monopólio na indicação, apresentação e divulgação dos candidatos, o que lhe traz uma relevância no quadro das

\footnotetext{
28 Nesse sentido Claudio Lembo assevera que "com o passar do tempo, as coisas se complicaram. Entraram em cena os marqueteiros e aquilo que deveria ser uma exposição direta se transformou em jogo eletrônico com o único objetivo: conduzir o espectador ao mundo dos sonhos. Este é um dos dramas das democracias contemporâneas. As eleições, aqui e em outros países, deixam de ser vencidas pelos melhores candidatos. É vitorioso aquele que contrata a melhor equipe de vídeo-mágicos.” (LEMBO, 2006, p. 9).
}

29 “O cidadão ao exercer o sufrágio, está agindo na sua condição essencial de liberdade previsto no art. I da Declaração dos Direitos do Homem, visto que no momento que ele pratica seu direito de sufrágio, sem interferências externas, com liberdade, além de estar exercendo a democracia na sua plenitude, estará escolhendo representante que, em tese, pensa e age na mesma sintonia dele, desta feita, as leis e as ações executivas elaboradas por esse eleito causarão menor impacto na vida do eleitor, ante a harmonia existente entre o eleito e o eleitor". (REIS, 2012, p. 90). 
instituições políticas, sendo suas funções a estruturação das atividades atinentes ao voto ${ }^{31}$, a função integradora-mobilizadora e participativa ${ }^{32}$, o recrutamento do pessoal político, ${ }^{33}$ a agregação de interesses e demandas ${ }^{34}$ e a formação de políticas públicas. ${ }^{35}$ (LEMBO, 1991).

Giovanni Sartori pontua que a democracia representativa pressupõe um Estado liberal-constitucional e a posição dos partidos, junto à democracia, é a de constituir um instrumento de controle do poder. ${ }^{36}$.

Muito embora, no caso brasileiro, o partido político seja o meio obrigatório para participação no pleito eleitoral, não se pode olvidar sua importância, que vai além de mero meio. Os partidos políticos representam a organização do poder social, seus valores e interesses, formando a classe política que propicia um procedimento para que a sociedade participe do poder. Ademais, promovem a educação política, formam e selecionam os que vão exercer, dominar e conquistar o poder político organizado. Dessa forma, os partidos políticos são "um canal de comunicação entre a estrutura social e o poder político organizado que simplifica e coordena os interesses e opiniões vigentes em uma comunidade." (SANCHEZ AGESTA, 1979, p. 255)

Ante as competências desempenhadas pelos partidos, pode-se dizer que a democracia representativa é a democracia pelos partidos. Manoel Gonçalves Ferreira Filho, ao discorrer sobre a democracia pelos partidos, afirma que o partido político é peça essencial, tem a função de estabelecer um programa exequível de governo (um plano capaz de ser executado como política de governo) e a de selecionar pessoas que se disponham a fazer executar esse

31 "As campanhas eleitorais são organizadas pelos partidos políticos que, em fase posterior, fiscalizarão as eleições e as respectivas apurações, acompanhando inclusive a diplomação dos eleitos.” (LEMBO, 1991, p. 62).

32 Os partidos se "responsabilizam pela mobilização da sociedade estimulando o eleitorado na procura de maior participação.” (LEMBO, 1991, p. 62).

33 O partido busca e seleciona no seio da sociedade indivíduos desejosos de se integrarem ao processo político ou à administração pública. (LEMBO, 1991, p. 62).

34 "Captam e canalizam os interesses e as demandas emergentes no âmbito da comunidade, acoplandolhes caráter político e transformando-as em programas gerais.” (LEMBO, 1991, p. 62).

35 "Formação das políticas públicas, mediante o desdobramento dos programas partidários em ação governamental." (LEMBO, 1991, p. 62).

36 “(...) a democracia não pode realizar-se sem a intermediação dos partidos, tem-se como referência o sistema partidarista como o sistema de agregação e canalização do voto”, tradução nossa. (SARTORI, 2012, p. 44). 
programa com a necessária eficiência, bem como atuar permanentemente no sentido de realizar a formação política do povo e perseguir os direitos fundamentais do homem, funcionando como um meio de intermediação entre governantes e governados. (FERREIRA FILHO, 1977, p. 47/49)

Nesse ponto, a crítica que se faz do modelo de democracia pelos partidos, no tocante ao caso brasileiro, é no sentido de que se encontra em crise, tanto sob o aspecto da seleção do político enquanto executor eficiente do programa de governo quanto com relação ao papel que os partidos deveriam desempenhar no sentido de realizarem a formação política do povo, perseguirem os direitos fundamentais e servirem como meio de intermediação entre governantes e governados.

Os partidos pecam, ainda, quanto à sua atuação permanente, que deveria ser no sentido de realizar a formação política do povo, perseguir os direitos fundamentais do homem e funcionar como um meio de intermediação entre governantes e governados, tendo em vista que, para manter o status quo não é desejável um eleitor formado e informado politicamente, não é interessante um homem detentor de seus direitos fundamentais que incluam a educação, a igualdade e a liberdade em suas várias acepções.

\section{Ferramentas da Democracia Participativa}

Nesse ponto, a democracia semidireta ${ }^{37}$ surge como "reflexo das novas exigências de participação política"(CAGGIANO, 1995, p. 95) e como resposta à crise da democracia representativa, modelo que não mais atende às expectativas da sociedade atual, voltada à defesa dos direitos humanos e dos direitos sociais. É neste panorama que florescem os ideais de uma democracia participativa, apresentada como um modelo capaz de aglutinar as virtudes da democracia representativa e ao mesmo tempo, sanar os vícios que permitem a utilização egoística da representação.

Como ferramentas da democracia semidireta, cita-se como exemplos, no caso brasileiro: o plebiscito, o referendo, a iniciativa popular, a ação popular, a ação civil pública, o mandado de injunção, o mandado de segurança e o orçamento participativo. ${ }^{38}$

\footnotetext{
37 No presente estudo, a democracia semidireta será utilizada no sentido de democracia participativa.

38 "Outro esquema, ora em voga, consiste na atribuição ao povo de instrumentos de manifestação direta de sua vontade quanto a decisões determinadas. É o modelo da democracia semidireta - que alguns denominam
} 
José Afonso da Silva explica que o plebiscito e o referendo foram definidos na lei "como consultas formuladas ao povo para que delibere sobre matéria de acentuada relevância, de natureza constitucional, legislativa ou administrativa" (SILVA, 2005, p. 223). A diferença entre as consultas é que no plebiscito a consulta é feita antes do ato legislativo ou administrativo, cabendo ao povo aprovar ou denegar o que lhe foi submetido. No caso do referendo, o povo é convocado posteriormente ao ato legislativo ou administrativo, o qual será ratificado ou rejeitado.

Para Luis Sanchez Agesta o referendo é uma votação que expressa o assentimento ou dissentimento do corpo eleitoral com relação a uma proposta de resolução de um órgão do poder, estando seu fundamento vinculado à doutrina do poder constituinte do povo ou da comunidade nos casos em que a resolução é inconstitucional ou afeta lei constitucional. É também um meio de educar o povo e trazer popularidade à resolução emitida. (SANCHEZ AGESTA, 1979, p. 298/299).

Tanto o referendo quanto o plebiscito são instrumentos da democracia operados de forma pessoal pelo povo que, in tese, seriam o retorno da democracia direta ateniense, modelo glorificado por espelhar o autogoverno, o governo sem intermediação. Contudo, esses instrumentos inseridos na democracia representativa podem significar um meio de manipulação política.

Retomando os instrumentos da democracia participativa, a iniciativa popular é aquela na qual o povo pode tomar para si a iniciativa legislativa e propor projetos de lei ao Legislativo. ${ }^{39}$ Para Canotilho, através da iniciativa popular, o povo pode pedir ao legislativo que edite uma lei sobre determinada matéria ou apresente um projeto de lei pronto e acabado (CANOTILHO, 2003, p. 295). Claudio Lembo pontua que é uma forma de afastar a concepção elitista da legislação, propiciando a possibilidade de que todos os setores sociais contribuam no campo legislativo de forma a defender interesses específicos (LEMBO, 1991, p. 44). Para Monica Herman Salem Caggiano é um instituto que ameniza as distorções do sistema representativo (CAGGIANO, 1987, p. 27).

de democracia participativa - prevendo referendo popular, iniciativa popular, plebiscito, recall, audiências públicas etc." (FERREIRA FILHO, 2010, p. 48).

39 No caso brasileiro deve-se atender aos requisitos previstos no artigo $61, \S 2^{\text {o }}$, da Constituição Federal. 
A iniciativa popular apresenta-se também como um meio encontrado pelo povo de preencher a apatia do legislativo quanto a certos temas que não interessam ser regulamentados por contrariar os interesses dos parlamentares. Como exemplo brasileiro, cita-se a Lei Complementar 135/2010 (Lei da Ficha Limpa) e o artigo 41-A da Lei 9840/1999. ${ }^{40}$

Outra ferramenta da democracia participativa é a ação popular, que segundo Claudio Lembo, é instituto cívico moralizador no Estado de Direito, uma vez que "a administração se subordina ao princípio da legalidade" (LEMBO, participação, p. 45).

A Ação popular no ordenamento jurídico brasileiro vem elencada no artigo $5^{\mathrm{a}}$, inciso LXXIII, da Constituição Federal ${ }^{41}$. Pode-se dizer que é um direito fundamental individual de caráter judicial, nos dizeres de Bruno César Lorencini (LORENCINI, ação, p.21/35). Muito embora a ação popular possa ser impetrada por um indivíduo, ela tutela, na realidade, direitos que dizem respeito à coletividade. Trata-se de um instrumento a posteriori de controle das decisões tomadas pelos representantes, sendo um instrumento de politização da sociedade.

O mandado de injunção previsto no artigo $5^{\circ}$, inciso LXXI, da Constituição Federal brasileira, nos dizeres de Gilmar Ferreira Mendes, "cuida-se de instrumento do processo constitucional voltado para a defesa de direitos subjetivos em face de omissão do legislador ou de outro órgão incumbido de poder regulatório" (MENDES, 2011, p. 489). É um sistema de controle abstrato de omissão com relação aos direitos, liberdades e prerrogativas vinculados ao status de brasileiro (FERREIRA FILHO, 2010, p. 51).

Manoel Gonçalves Ferreira Filho adverte que, em verdade, o mandado de injunção foi pensado pelo legislador em razão de que alguns direitos não são efetivados em razão de falta de norma regulamentadora e, nesses casos, o cidadão tem condições de suprir essa lacuna exigindo que tal norma seja editada. (FERREIRA FILHO, 2010, p. 349/350)

O mandado de segurança destina-se a proteger direito individual ou coletivo, líquido e certo, contra ato ou omissão de autoridade pública não amparado por habeas corpus ou habeas data em casos de ilegalidade ou abuso de poder perpetrados por autoridade pública ou

40 A Lei 135/2010 visa à defesa da probidade e da moralidade no exercício de mandato na administração pública e a Lei 9840/99 em seu artigo 41-A tem por escopo a moralização das eleições.

$41 \quad$ Art. $5^{\circ}$ LXXIII - “qualquer cidadão é parte legítima para propor ação popular que vise a anular ato lesivo ao patrimônio público ou de entidade de que o Estado participe, à moralidade administrativa, ao meio ambiente e ao patrimônio histórico e cultural, ficando o autor, salvo comprovada má-fé, isento de custas judiciais e do ônus da sucumbência”. 
agente da pessoa jurídica no exercício de atribuições do Poder Público. ${ }^{42} \mathrm{Na}$ concepção de Manoel Gonçalves Ferreira Filho, o mandado de segurança, de criação brasileira, foi previsto para suprir uma lacuna deixada de proteção de outros direitos que não o de locomoção (habeas corpus) e o de informação (habeas data). (FERREIRA FILHO, 2010, p. 347).

$\mathrm{O}$ orçamento participativo tem por fundamento a cooperação das associações representativas no planejamento do orçamento público. As características essenciais do orçamento participativo são: 1) participação aberta a todos os cidadãos sem nenhum status especial atribuído a qualquer organização, inclusive as comunitárias; 2) combinação de democracia direta e representativa, cuja dinâmica institucional atribui aos próprios participantes a definição das regras internas; e 3) alocação dos recursos para investimentos baseada na combinação de critérios gerais e técnicos. Ou seja, compatibilização das decisões e regras estabelecidas pelos participantes com as exigências técnicas e legais da ação governamental, respeitando também os limites financeiros. Os orçamentos participativos são discutidos em assembleias regionais, cuja participação é individual aberta a todos os membros da comunidade; é aplicado um princípio distributivo capaz de reverter desigualdades preexistentes em relação à distribuição de bens públicos; desenvolve-se "tabelas de carência" em fase anterior à deliberação, com fito de identificar as áreas em que há mais necessidade de recursos e há mecanismos de compatibilização entre o processo de participação, de deliberação e o poder público.

\section{CONCLUSÃO}

A democracia é um regime político que introduz a vontade popular na condução do Estado e da vida em sociedade, é uma forma política de atendimento dos anseios e necessidades do homem.

Sob este aspecto, o atendimento dos anseios e necessidades do homem está diretamente relacionado à sua participação. A democracia perecerá ou florescerá na exata medida da participação política do povo.

42 Constituição Federal brasileira artigo $5^{\circ}$, inciso LXIX. 
A democracia possível, nos tempos atuais, é a representativa, constituindo o ápice participativo a eleição de representantes, que terão a missão de refletir a vontade popular.

Neste ponto depara-se com duas questões, a imaturidade cultural política do povo na eleição de representantes que de fato os representarão e a crise da representatividade oriunda da degeneração dos partidos políticos.

Como solução para a prosperidade da democracia e ajustamento da representatividade impõem-se os meios de participação direta do povo no locus governamental, tais como o plebiscito, o referendo, a iniciativa popular, a ação popular, a ação civil pública, o mandado de injunção, o mandado de segurança e o orçamento participativo.

O aprimoramento das ferramentas da democracia representativa conforme as críticas tecidas neste trabalho, bem como a adoção e ampliação da aplicação das ferramentas da democracia participativa revelam-se importantes ao fortalecimento do Estado de Direito que tem por um dos seus pilares a própria democracia, e portanto, o atendimento dos anseios da sociedade de forma individual e coletiva.

\section{Bibliografia}

http://www.dec.ufcg.edu.br/biografias/Clistene.html. Acesso em: 20 jul. 2013.

ALVES, José Eustáquio Diniz. Os 80 anos do voto feminino no Brasil. Disponível em http://www.ecodebate.com.br/2012/02/24/80-anos-do-direito-de-voto-feminino-no-brasilartigo-de-José-eustaquio-diniz-alves/. Acesso em: 15 fev.2014.

ARENDT, Hannah. Origens do Totalitarismo. São Paulo: Cia das Letras, 1989.

ARENDT, Hannah. A condição humana. 10. ed. Rio de Janeiro: Forense Universitária, 2007.

AZEVEDO, Luiz Carlos de. O direito grego antigo. Osasco: FIEO, 1999.

BAUMAN, Zygmunt. Modernidade Líquida. Rio de Janeiro: Jorge Zahar, 2001.

BONAVIDES, Paulo. Ciência política. São Paulo: Malheiros, 2012.

CAGGIANO, Monica Herman Salem. Sistemas eleitorais x representação política. São Paulo: Centro Gráfico do Senado Federal, 1987.

CAGGIANO, Monica Herman Salem. Oposição na política: proposta para uma rearquitetura da democracia. São Paulo: Angelotti, 1995. 
CAGGIANO, Monica Herman Salem. Direito parlamentar e direito eleitoral. Barueri, SP: Manole, 2004.

CAGGIANO, Monica Herman Salem.. Da operação eleitoral: enquadramento jurídico. In: CAGGIANO, Monica Herman Salem (coord.); MESSA, Ana Flávia; ALMEIDA, Fernando Dias Menezes de (Orgs.). Direito Eleitoral em Debate: estudos em homenagem a Claudio Lembo. São Paulo: Saraiva, 2013.

CANOTILHO, José Joaquim Gomes. Direito Constitucional e Teoria da Constituição. 7. ed. 13. reimp. Portugal, Coimbra: Almedina, 2003.

CANOTILHO, José Joaquim Gomes. Direito constitucional e teoria da constituição. Coimbra: Almedina, 2003.

COMPARATO, Fábio Konder. A Afirmação Histórica dos Direitos Humanos. 8. ed., São Paulo: Saraiva, 2013.

CUNHA, Paulo Ferreira da. Democracia, esteio dos Direitos Humanos in FERRAZ, Anna Candida da Cunha et al. (Orgs). Direitos Humanos Fundamentais: Doutrina, Prática e Jurisprudência. Niterói, RJ: Impetus, 2013.

DAHL, Robert. Sobre a Democracia. Brasília: UNB, 2001.

DANTAS, Luís Rodolfo de Souza at al. A democracia nascente: Atenas depois de Clístenes. Estudos Jurídicos em homenagem ao professor Silas Rodrigues Gonçalves. São Paulo: Scortecci, 2006.

DUVERGER, Maurice. Los Partidos Políticos. México: Fondo de Cultura Económica, 1957.

FERREIRA FILHO, Manoel Gonçalves. Curso de direito constitucional. 36a edição revisada e atualizada. Sâo Paulo: Saraiva, 2010.

FERREIRA FILHO, Manoel Gonçalves. A reconstrução da democracia: ensaio sobre a institucionalização da democracia no mundo contemporâneo e em especial no Brasil. Sâo Paulo: Saraiva, 1979.

FERREIRA FILHO, Manoel Gonçalves. Sete vezes democracia. São Paulo: Convívio, 1977.

FERREIRA FILHO, Manoel Gonçalves. Princípios fundamentais do direito constitucional: $o$ estado da questão no início do século XXI, em face do direito comparado e, particularmente, do direito positivo brasileiro. São Paulo: Saraiva, 2010.

LEMBO, Claudio. Participação política e assistência simples no direito eleitoral. Rio de Janeiro: Forense Universitária, 1991.

LEMBO, Claudio. Eles temem a liberdade. Barueri: Minha Editora; São Paulo: CEPES, 2006. 
LEMBO, Claudio. Participação política e assistência simples no direito eleitoral. Rio de Janeiro: Forense Universitária, 1991.

LORENCINI, Bruno César. A ação popular como instrumento democrático. In: MESSA, Ana Flávia; FRANCISCO, José Carlos (coords.). Ação popular. São Paulo: Saraiva, 2013.

MENDES, Gilmar Ferreira; BRANCO, Paulo Gustavo Gonet. Curso de direito constitucional. $6^{\text {a }}$ edição revisada e atualizada. São Paulo: Saraiva, 2011.

REIS, Márlon. Direito eleitoral brasileiro. Brasília: Alumnus,2012.

SANCHEZ AGESTA, Luis. Princípios de teoría política. Madrid: Editora Nacional, 1979.

SARTORI, Giovanni.?Qué es la democracia? Madrid: Santillana Ediciones Generales, 2007.

SARTORI, Giovanni. Elementos de teoría política. Madrid: Alianza Editorial, 2012.

SILVA, José Afonso da. Comentário contextual à constituição. São Paulo: Malheiros, 2005. 